\title{
Preparation of Specific Antisera Against Chicken Lens Protein Components
}

When using immunological systems, antibodies against one particular antigen can sometimes hardly be obtained. In our experiments with chicken-lens antigens, this problem is met with constantly.

An extract of the chicken-lens homogenate is generally assumed to contain 3 groups of proteins listed as $\alpha-, \beta$ and $\gamma$-crystallines (MöRNER ${ }^{1}$ ). Analyses $a_{s} d$ and $f$ in the Figure show an immunoelectrophoretical pattern of total chicken-lens extract against anti-chicken-lens serum. For the chicken there is one special $\beta$-component, whereas for many other species an $\alpha$ or other components are common. In earlier work we tried to isolate protein fractions by using DEAE cellulose combined with gel filtration on Sephadex (VAN DOORENMAALEN, Hornders and $Z_{\text {WAAN }}{ }^{2}$ ). Such a fraction presumably contains 1 antigen; however, when injected into rabbits it produces antisera still containing antibodies against some other antigens as well. Therefore, a new procedure was designed, which appeared to be more successful.

The first step of this procedure was to separate the $\alpha$-antigen from the total lens extract by gel filtration on Sephadex $\mathrm{G}-200$ with $T$ ris- $\mathrm{HCl}$ buffer, $\mathrm{pH} 7.3(0.1 M$ Tris $\mathrm{HCl}+1 M \mathrm{NaCl})$. The $\alpha$-crystalline, having a high molecular weight, filtrates faster through the column, separating itself from the remaining proteins. Repeated gel filtration of the remaining mixture yields a fraction which is completely free from $\alpha$-crystalline. This fraction is designated here as Sigma-minus-alpha fraction $(\Sigma-\alpha)$. The absence of the $\alpha$-crystalline was demonstrated by
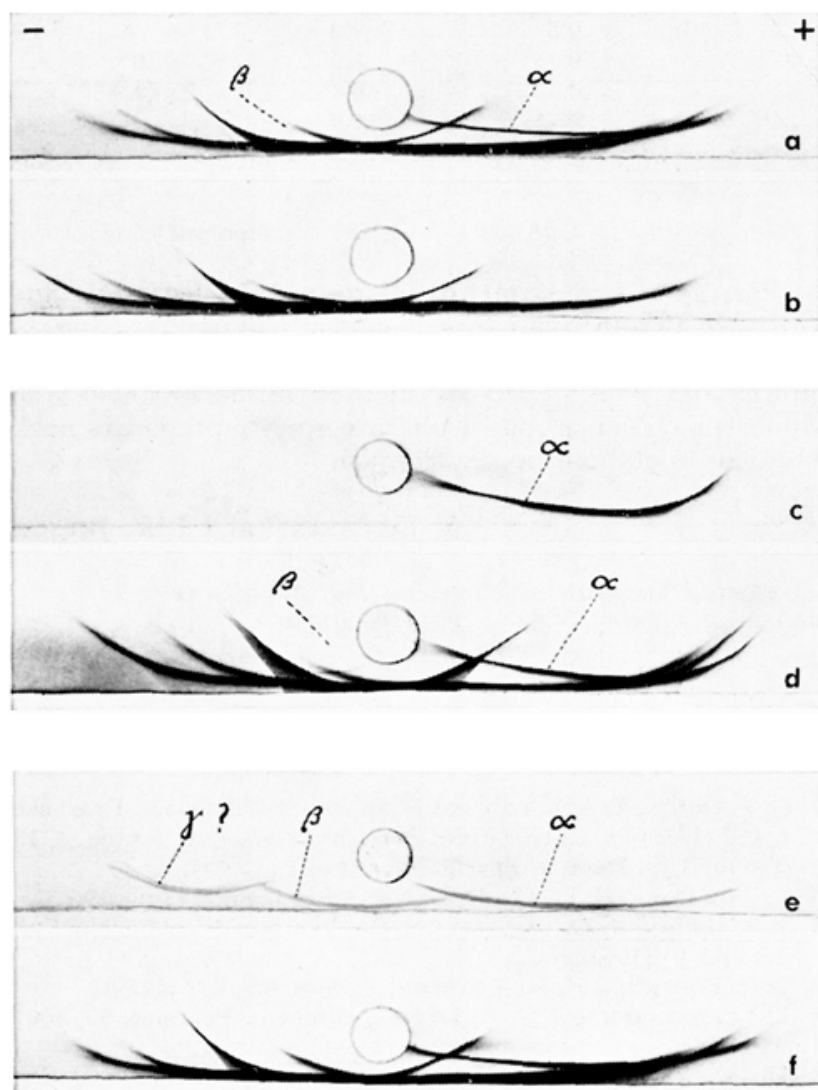

$a b$, cd and ef are immunoelectrophoretical analyses performed at the same time. immunoelectrophoresis as is shown in analysis $\mathrm{b}$ in the Figure.

In the second phase the protein mixture $\Sigma-\alpha$ was used to produce immunological tolerance (Drxon and MAURER ${ }^{3}$ ). For this purpose the $\Sigma-\propto$ fraction was injected, from the first day, into new-born rabbits of various litters. Intraperitoneal as well as s.c. injections, combined with Freund adjuvant, were given. The antigen injections were given according to various time schedules and in different quantities, the results of which will be published later.

In the final phase, when the tolerant young rabbits were 6 weeks old, total lens extract, dissolved in normal saline and incorporated in Freund adjuvant, was injected according to a routine immunization schedule.

At 9 weeks, blood samples were taken from the rabbits and tested immunoelectrophoretically against total lens extract as well as the $\Sigma-\alpha$ fraction. In analysis $\mathrm{c}$ in the Figure, only 1 line is seen caused by the precipitation of anti- $\alpha$-crystalline serum with only the $\alpha$-crystalline of the total lens extract. The serum tested against the $\Sigma-\alpha$ fraction produces no line at all. Injections of total lens were continued in the tolerant young rabbits after they had passed the tolerance period. Gradually a production of antibodies against other antigens was observed by repeated immunoelectrophoresis, of which analysis $e$ in the Figure is an example. Control rabbits from the same litters were immunized with total lens extract when they were 6 weeks old. Antibodies against all lens antigens developed normally as can be seen by immunoelectrophoresis. The fact that so many tolerant cases were obtained (9 rabbits) may serve as a proof for the reliability of the procedure described (see also VAN DoorenMAALEN ${ }^{4}$ ).

An attempt was also made to apply the procedure mentioned above to the $\beta$-component of the chicken-lens (Van Doorenmaalen, Hoenders and $Z_{\text {WaAn }}{ }^{2}$ ). As the number of successful cases is too small as yet, the experiments are still in progress.

Zusammenfassung. Kaninchen wurden gegenüber Eiweissfraktionen, aus denen chromatographisch ein bestimmtes Protein entfernt war, tolerant gemacht. Durch Injektion eines ungereinigten Präparats des eliminierten Proteins während der toleranten Phase war es aber trotzdem möglich, einen für dieses Protein spezifischen Antikörper hervorzurufen.

W. J. Van Doorenmaalen, S. K. Brahma and $\mathrm{H}$. J. HOENDERS

Department of Medical Anatomy and Embryology,

State University of Utrecht and Department of

Biochemistry, University of Nijmegen

(The Netherlands), 14 August 1967.

I C. Tu. Mörner, Hoppe-Seylers Z. Physiol. Chem, 18, 61 (1894),

2 W. J. Van Doorenmaalen, H. J. Hoenders and J. ZwaAn, in Protides of the Biological Fluids (Ed. H. PeETERs, Elsevier, Amsterdam 1964).

3 F. J. Dixon and P. H. Maurer, J. exp. Med. 107, 245 (1955).

4 W. J. van Doorenmaalen, in New Methods in Embryology (Ed. E. WolfF, Hermann, Paris 1966). 